\title{
Design and Implementation Data Logger with Integrated Circuit Multiplexer for Solar Panel Park
}

\author{
Ali Basrah Pulungan ${ }^{1,2}$, Lovely Son ${ }^{1}$, Syafii Syafii ${ }^{3}$, \\ Syamsul Huda ${ }^{1}$, Ubaidillah Ubaidillah ${ }^{4}$ \\ ${ }^{1}$ Department of Mechanical Engineering, Limau Manis,Universitas Andalas, Indonesia \\ ${ }^{2}$ Department of Electrical Engineering, Universitas Negeri Padang, Air Tawar, Padang, Indonesia \\ ${ }^{3}$ Department of Electrical Engineering, Limau Manis, Universitas Andalas, Indonesia \\ ${ }^{4}$ Department of Mechanical Engineering, Solo, Universitas Sebelas Maret, Indonesia
}

\begin{abstract}
This article describes the data logging technique for large-scale solar panels system. The input data of the developed data logger can be increased significantly by optimizing the Integrated Circuit (IC) Multiplexer analog input. Multiplexer ICs are suitable for recording parameter data on largescale solar panel systems, which are often called solar panel parks. The data logger system consists of an Arduino microcontroller equipped with a current sensor, a voltage sensor, multiplexer IC, RTC, and an SD card. The obtained data is stored on the SD-card every 5 minutes, in the form of a .txt file with the format of the day, date, time, current value, and the voltage value of each solar panel. The test results show that data acquisition on the solar panel park using a data logger with multiplexer IC has been able to store and display a large number of solar panel data.
\end{abstract}

Keywords - Data logger, arduino uno, integrated circuit multiplexer, solar panel park.

DOI: $10.18421 /$ TEM111-54

https://doi.org/10.18421/TEM111-54

Corresponding author: Lovely Son,

Department of Mechanical Engineering, Limau Manis, Universitas Andalas, Indonesia.

Email: lovelyson@eng.unand.ac.id

Received: 24 November 2021.

Revised: 13 February 2022.

Accepted: 18 February 2022.

Published: 28 February 2022.

(c) BY-NC-ND (C) 2022 Ali Basrah Pulungan et al; published by UIKTEN. This work is licensed under the Creative Commons Attribution-NonCommercial-NoDerivs 4.0 License.

The article is published with Open Access at https://www.temjournal.com/

\section{Introduction}

The great attention to alternative energy sources, especially solar energy causes the increasing use of solar panel technology [1]. The operation of solar panels requires monitoring and recording of parameters, such as temperature, radiation, voltage, and current [2]. The ability to store a large number data for a long time makes data loggers is very popular for solar panel application.

The data logger main functions is monitoring and recording data from transducers, computers, and sensors [3]. The use of data loggers in solar panel systems has made data recording easier without regular monitoring by the user. However, the available data recording devices are generally expensive, and some additional features are sometimes not needed in solar panel monitoring [4]. Operations that require a Personal Computer (PC) all the time make the device require an additional power supply and increase the complexity of the process [5]. The availability of input ports and data storage capacity also determines the flexibility of using the data logging system in different solar panel applications, such as large-scale solar panels. Some data logger devices can store large data but lack an input port or vice versa.

This research develops alternative data logger systems that can be used as an option for large-scale solar panels. This data logger uses hardware and software that is easy to obtain and develop. Some important features of this data logger are including: independent operation without being connected to a PC, easy to build and operate, able to accept relatively many inputs using multiplexer ICs and capability to store large capacity data files. 


\section{Literature Review}

Data capacity and storage time are the main parameters that determine the reliability of the data logger device. Several studies related to solar panel data acquisition systems have been conducted. Recording of solar panel output power and solar radiation intensity in Solar Power Generation systems using Arduino Uno and MicroSD cards as data storage media with MS Excel data format have been investigated by [6]. The power parameters are obtained using a voltage sensor module with a voltage divider principle and a current sensor with a shunt resistor. The radiation intensity is obtained from the solar power meter sensor. Furthermore, Mahzan et al. [4] developed a data recording system using two SD cards to store a lot of data for a long time measurement. The collected data consist of electrical and meteorological parameters. This data logger prototype uses the Atmel Atmega 328 microcontroller, DS1307 Real Time Clock (RTC). Hereafter, Suryawinata et al. [7] created a real-time monitoring system for voltage and current on solar panels using ATmega 328 and real-time clock DS1307. The data is stored on the SD-card every 15 minutes.

For the design and accurate data logger, Fuentes et al. [5] created a low-cost, autonomous, and flexible photovoltaic (PV) monitoring system, making it very attractive for research and solar energy applications in developing countries. This data logger uses the Arduino open-source electronic platform, meeting the accuracy requirements set by the IEC61724 standard related to photovoltaic monitoring systems. On the other hand, El Hammoumi et al. [8] provide a new technique for real-time instrumentation of solar panel characteristics such as voltage, current, and power in the form of low-cost virtual devices. Data is presented in Excel using PLX-DAQ Excel Macro data acquisition and displays data in current-voltage curves (IV) format and power-voltage (PV) curves.

To make it easier to observe, Singh and Thakur [3] designed a prototype data logger based on Arduino Uno, which can remotely monitor and record voltage, current, power, and energy data from two solar panels using an SD card or Bluetooth-enabled Android phone memory. From the data display, Touati et al. [9] carried out monitoring and recording of solar panels in real-time based on LabView. Monitoring is carried out to monitor the effect of dust exposure on the maximum power output of the PV module in a long time and harsh environment.

\section{Material and Methods}

This research proposes an alternative data logger system for large-scale solar panels park using easy to obtain components and programmed using open source program. In addition, this data logger can receive a large amount input data because it utilized the optimized analog input on the Arduino Uno board using an Integrated Circuit (IC) Multiplexer.

Figure 1 shows a block diagram of a data logger designed for recording current and voltage on four solar panels, consisting of a sensor module, microcontroller, IC MUX (Multiplexer), RTC, and SD card.

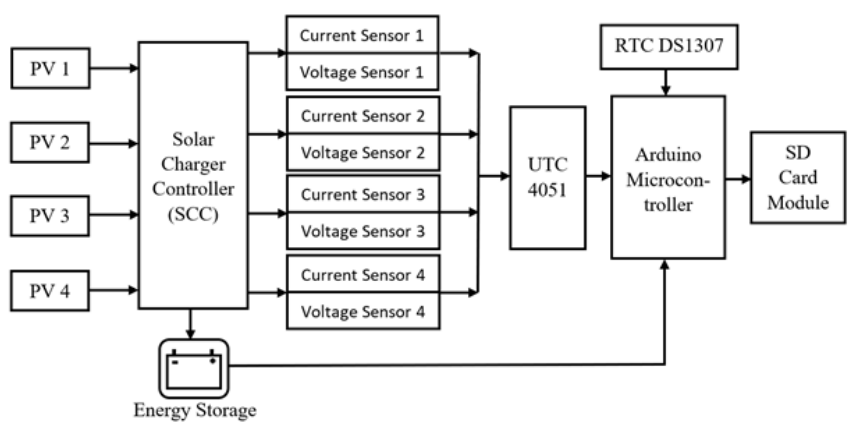

Figure 1. Block diagram for the proposed data logger

\subsection{Specification}

\section{a. Microcontroller}

The microcontroller is a simple chip that can be programmed and used for control-oriented commands. Arduino Uno is an open-source microcontroller board based on the ATmega328, as shown in Figure 2. Arduino Uno has 14 digital I/O (input/output) pins, 6 of which can be used as PWM outputs, six analog input pins, using a crystal 16 $\mathrm{MHz}$ between pins A0 to A5, 10-bit resolution, has TTL serial communication, Serial Peripheral Interface (SPI) and Inter-Integrated Circuit (I2C). This is all needed to support an ATMega328P microcontroller circuit with the pin configuration shown in Figure 3.

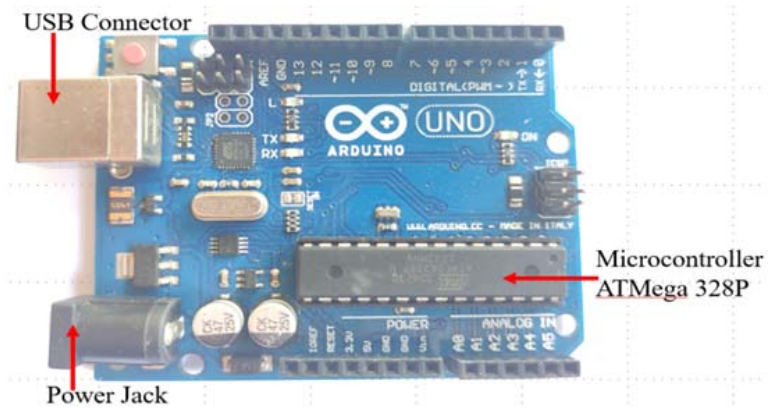

Figure 2. Board Arduino ATmega328 


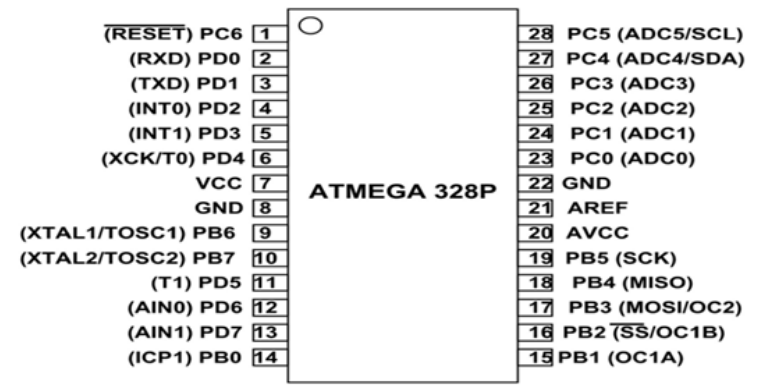

Figure 3. ATMega 328 pin configuration

\section{b. Voltage Sensor}

The solar panel voltage is measured using a voltage sensor module, as shown in Figure 4. The module used in this study has a maximum input voltage of $25 \mathrm{VDC}$ and a maximum output voltage of 5 VDC. The output on the voltage sensor is connected to the Arduino analog input pin. The availability of analog pins makes Arduino able to read a maximum voltage value of 5 VDC. The data received by Arduino is in the form of an analogdigital converter (ADC). The analog voltage from the voltage sensor module can be calculate from the arduino digital data using equation (1) as follows:

$$
V=\left(\frac{A D C}{1023}\right) 5
$$

With;

$$
\begin{array}{ll}
\text { ADC } & : \text { Read ADC value } \\
1023 & : \text { Maximum ADC value }(10 \text { bits }) \\
5 & : \text { Arduino ADC reference voltage (default) }
\end{array}
$$

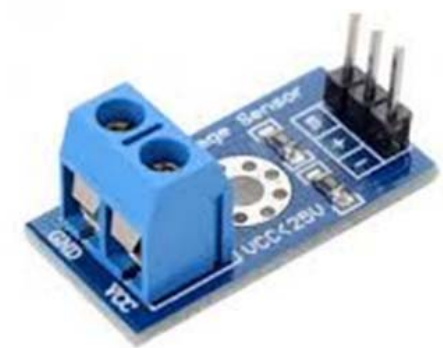

Figure 4. Voltage sensor module

If the measured voltage value between 0-5 volts, the analog data can directly connected to the arduino analog pin, meanwhile if the voltage range is greater than 5 volts, an additional circuit should be used, namely a voltage divider, as shown in Figure 5. The voltage ratio is shown in equation (2).

$$
V_{\text {out }}=\frac{R_{2}}{R_{1}+R_{2}} x V_{\text {in }}
$$

By specifying some parameters, such as;

$\mathrm{V}_{\text {in }}=$ Maximum rated voltage (volts)

$\mathrm{V}_{\text {out }}=\mathrm{ADC}$ voltage (set maximum 5 volts)

$\mathrm{R}_{1} \quad$ adjustable (ohms)
Then the value of $\mathrm{R}_{2}$ can be calculated using equation (2).

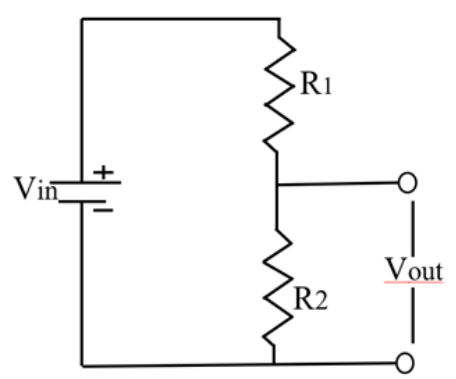

Figure 5. Voltage divider circuit

\section{c. Current Sensor}

The used current sensor is ACS712-30A which has a current capability of up to 30 Ampere as shown in Figure 6. ACS712 is a half effect current sensor that is precise as a direct current (DC) and alternating current (AC) sensor in current readings in the industrial, automotive world, commercial and communication systems. The output of the current sensor is a DC voltage. The changes produced by the current sensor output are minimal, about $100 \mathrm{mV}$ for every 1-ampere change. When current flows on the conductor's surface, it will have a magnetic field sensed by the integrated hall effect IC, converted to a voltage. This sensor makes it possible not to use an optoisolator because the current input terminal and the output are electrically isolated.

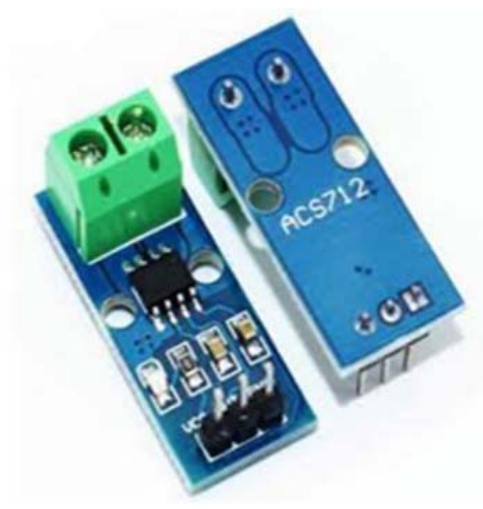

Figure 6. ACS712 hall effect current sensor module

\section{d. Real-Time Clock (RTC)}

Real-Time Clock (RTC) is a module with an IC and a battery that stores time and date information continuously even though it does not receive data from outside, as shown in Figure 7. In this data logger design using RTC DS1307, serial I2C communication, working voltage $5 \mathrm{VDC}$, and internal battery 3 VDC. 


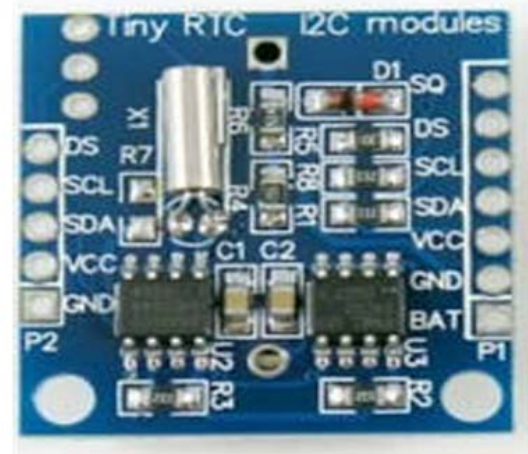

Figure 7. DS1307 Real Time Clock module

\section{e. SD-Card Module}

The SD-Card module is a module that is used to read and store data on a memory card using the Serial Peripheral Interface (SPI) interface. This module is connected to Arduino Uno to store various parameters such as time, voltage, the current generated by the solar panel and is also widely used in multiple applications that require database storage such as queuing systems, attendance, data logging, parking, and others. The SD-Card module in this data logger design has a regulator IC of $3.3 \mathrm{VDC}$, a working voltage of $5 \mathrm{VDC}$, and is equipped with a 4 GB micro SD card, as shown in Figure 8.

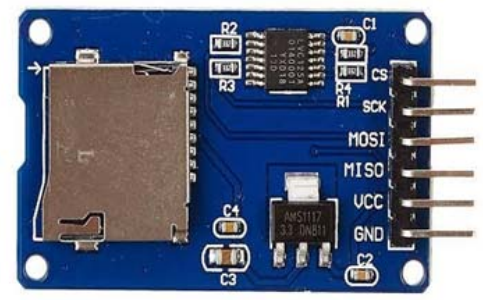

Figure 8. SD-Card module

\section{f. IC Multiplexer}

The limitation of analog pins on the Arduino board results in limited data input for the data logger, resulting in the need to increase the capacity of the Arduino board. This can be overcome by using a Multiplexer IC. The design of this data logger uses a multiplexer IC UTC4051 which has eight input pins $(\mathrm{X} 0-\mathrm{X} 7)$ and one output pin (X), three pins as control/switch (A, B, and C) 10-bit resolution, and a working voltage of $5 \mathrm{VDC}$. The pin configuration shown in the figure is shown in Figure 9.

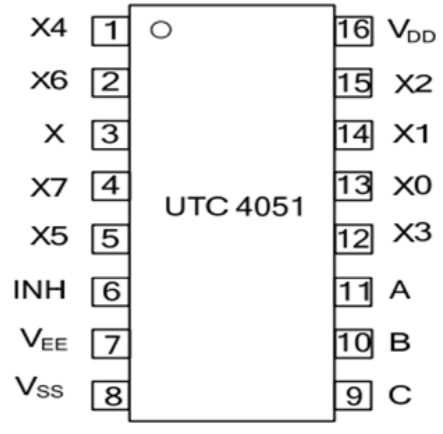

Figure 9. UTC 4051 pin configuration

\section{g. Design}

The voltage source of the designed data logger system is obtained from a 12 VDC battery and $5 \mathrm{~A}$ current. The $12 \mathrm{VDC}$ voltage is reduced to $5 \mathrm{VDC}$ as the Arduino voltage supply using a buck converter. The solar charge controller is used to charge the battery automatically so that the power needed for the circuit can be available for a long time. Then the measurement data will be sent and saved to the SDCard with the txt file extension.

Figure 10 shows a schematic circuit of the designed data logger system. Monitoring and recording is carried out on four solar panels. While the process flow diagram that occurs in the microcontroller is shown in Figure 11.

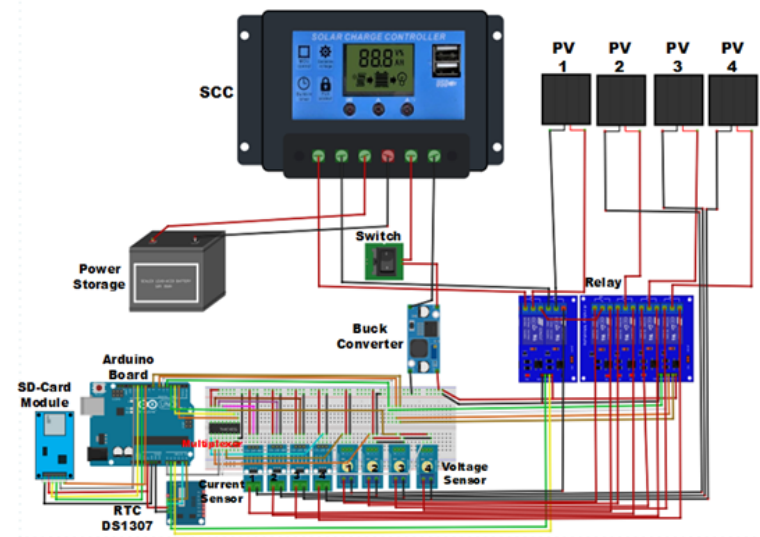

Figure 10. The schematic diagram of the proposed data logger connected to the PV system for testing 

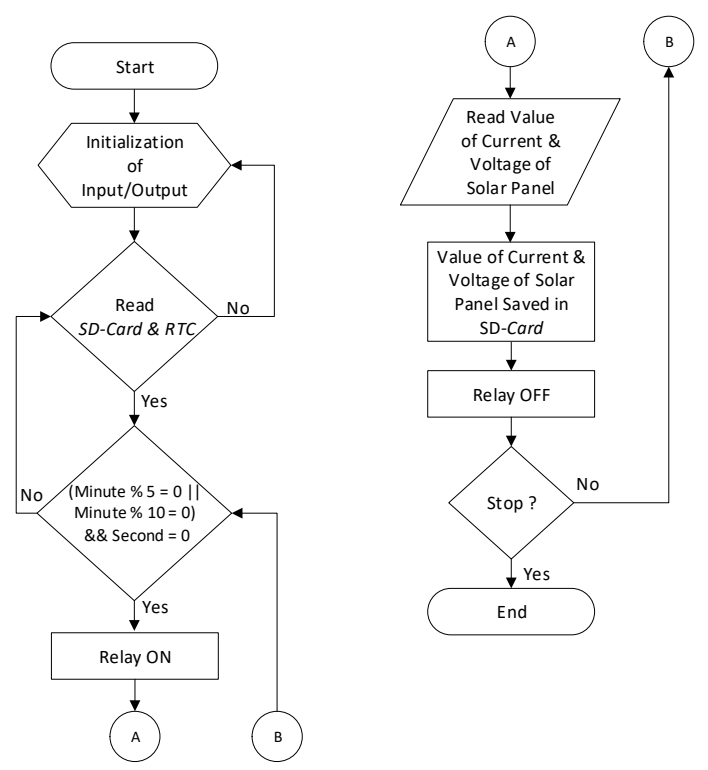

Figure 11. Flowchart of the process that occurs in the microcontroller

The software on the data logger is designed using the Arduino programming language that can support the Atmega 328 microcontroller. Arduino programming uses the RTC DS1307 library, which consists of RTClib.h and Wire.h, while the SD card is SPI.h and SD.h, as shown in Figure 12.

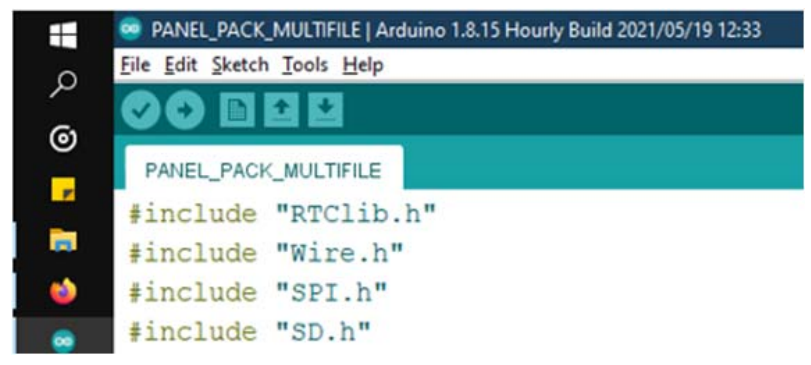

Figure 12. Libraries on programming

\subsection{Experimental Setup}

The designed data logger system is implemented by measuring the current and voltage of four solar panels. Each of these solar panels has the exact specifications with a capacity of $50 \mathrm{Wp}$. The data collection process was carried out on the rooftop of the Integrated Laboratory of the Faculty of Engineering, Padang State University, West Sumatra, Indonesia, starting at 07.45 AM - 04.40 PM. The data obtained will be stored on the SD-card every 5 minutes, in the form of a txt file with the format of the day, date, time, current value, and the voltage value of each solar panel. The complete schematic of the four solar panels used for testing the developed data logger is shown in Figure 13. While Figure 14 shows the data logger system that has been completed.

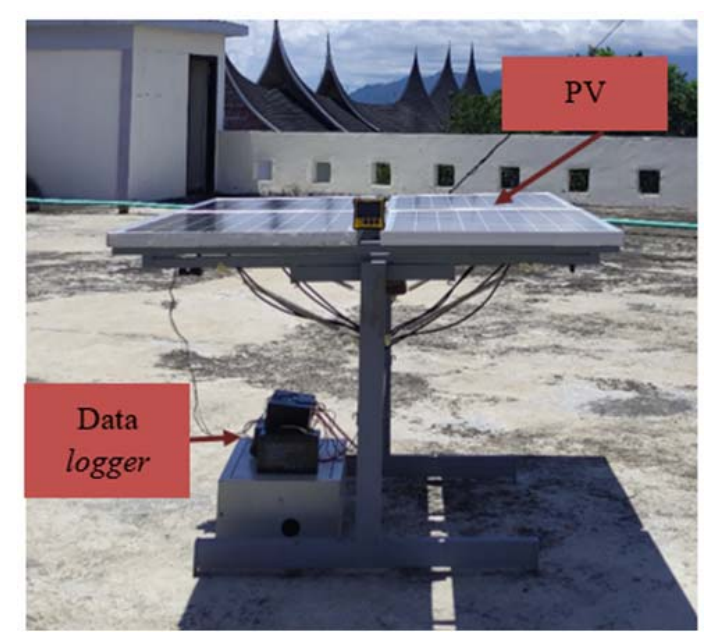

Figure 13. Experimental setup of the data logger to measure PV parameter

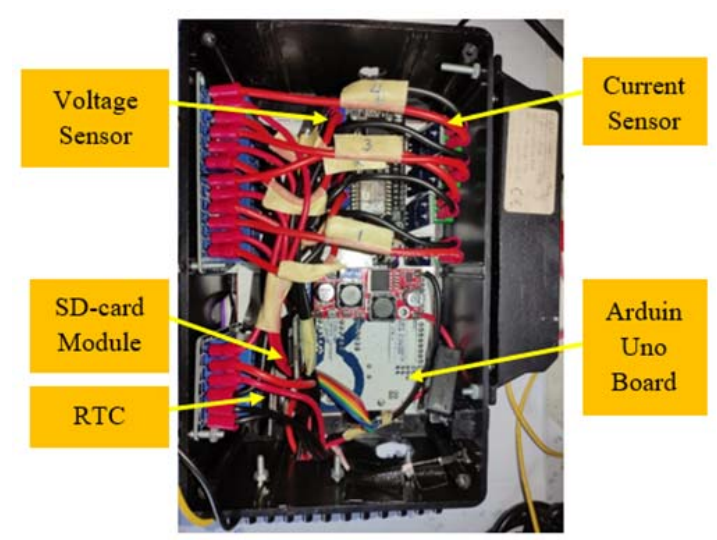

Figure 14. Complete proposed data logger

\section{Results and Discussion}

After designing and building an Arduino-based data logger, the next step is to measure voltage and current from four panels. A partial view of the developed program is shown in Figure 15.

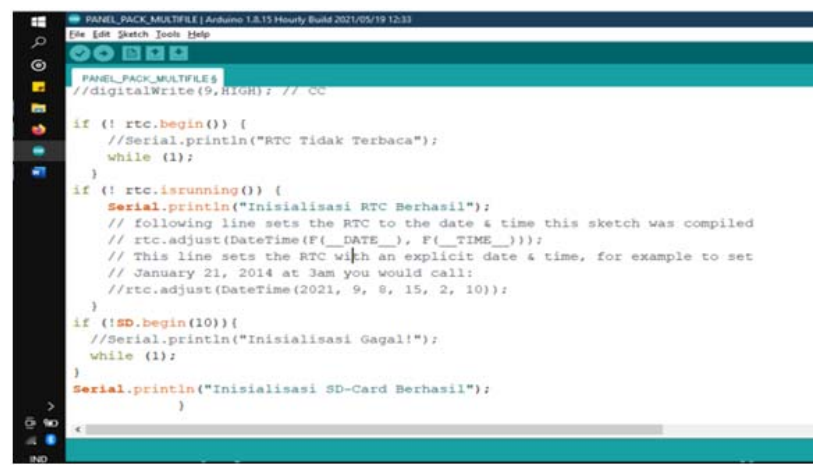

Figure 15. Partial view of the program

The data obtained at the time of measurement is stored on the SD Card, showing results by the performance design of the tool written in a programming language. The results obtained in the form of voltage and current data for each PV stored in the notation V1 for the voltage at PV1, V2 for the 
voltage at PV2, V3 for the voltage at PV3, V4 for the voltage at PV4. The measured current is also written with I1, I2, I3, I4 for each PV. The measurement data is saved in the form of a txt file that can be opened in a notepad, as shown in Figure 16.

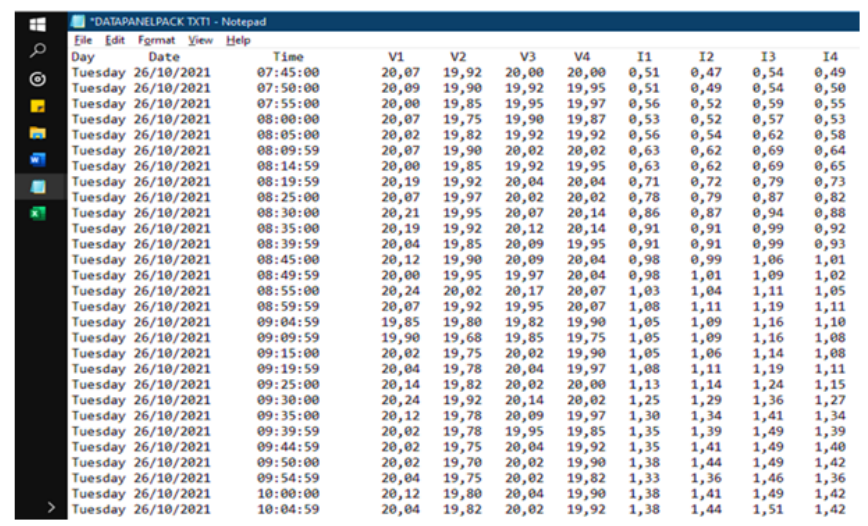

Figure 16. Data saved in SD card in the form of a txt file

The txt file stored on the SD Card can be converted directly in the form of an excel file as shown in Figure 17.

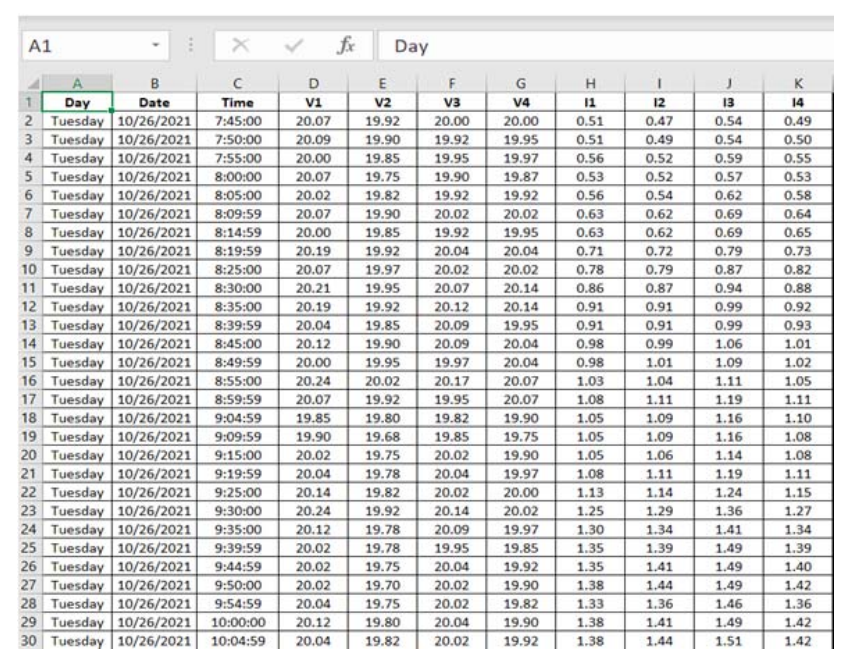

Figure 17. Data saved in the form of a excel file

The data obtained during the measurement period shows that each solar panels output voltage as shown in Figure 18 and output current as shown in Figure 19 are the same characteristics. The voltage value tends to be constant during the measurement period. The current value increases and tends to be stable in the $11.00 \mathrm{AM}-01.00$ period PM on each PV. This value shows the effect of the level of sunlight received by the solar panel at the time of measurement.

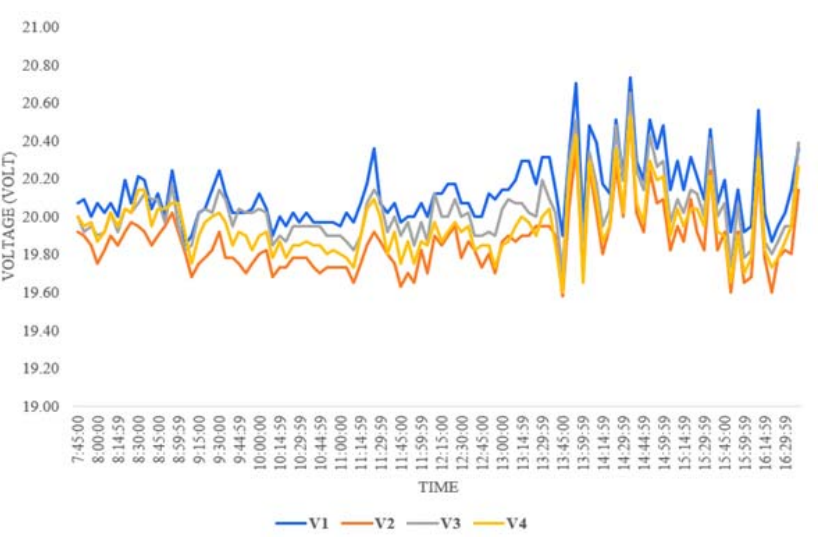

Figure 18. Solar panel output voltage

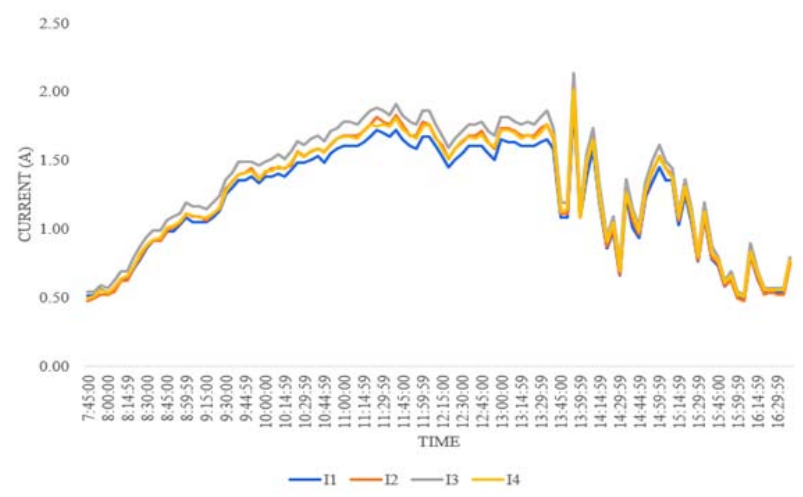

Figure 19. Solar panel output current

Overall the process carried out in making data loggers with multiplexer ICs starting from coding in programming languages to displaying measurement data in the form of excel files, shows the performance of this tool is following the design. Furthermore, multiplexer ICs in this tool can serve many sensors, such as four current sensors and four voltage sensors. This shows that the use of this IC is very effective in reducing the number of analog inputs on the Arduino board port.

\section{Conclusion}

Alternative data loggers using multiplexer ICs have been designed, built, and implemented. As per the specifications of commonly used components, easy to obtain, and open-source programming language. The multiplexer IC on this data logger can receive eight inputs from sensors with one output for the Arduino board analog input pin without reducing the effectiveness of the device's performance. 


\section{Acknowledgements}

The authors would like to thank Lembaga Penelitian dan Pengabdian Masyarakat Universitas Negeri Padang for funding this work with a contract number: 916/UN35.13/LT/2021.

\section{References}

[1]. Pulungan, A. B., Lovely Son, S., \& Huda, S. (2021). Improvement of a Solar Panel Tracking System using Additional Mass Position Adjustment. Geomate Journal, 21(86), 92-99.

[2]. Pulungan, A. B., \& Goci, D. S. (2021). Penggunaan Sistem Data logger Dalam Pencatatan Data Parameter Panel Surya berbasis Mikrokontroler. JTEV (Jurnal Teknik Elektro dan Vokasional), 7(2), 337-344.

[3]. Singh, T., \& Thakur, R. (2019). Design and development of PV solar panel data logger. International Journal of Computer Sciences and Engineering (IJCSE), 7. doi: $10.26438 / \mathrm{ijcse} / \mathrm{v} 7 \mathrm{i} 4.364369$

[4]. Mahzan, N. N., Omar, A. M., Rimon, L., Noor, S. M., \& Rosselan, M. Z. (2017). Design and development of an arduino based data logger for photovoltaic monitoring system. Int. J. Simul. Syst. Sci. Technol, 17(41), 15-1.

doi: 10.5013/IJSSST.a.17.41.15
[5]. Fuentes, M., Vivar, M., Burgos, J. M., Aguilera, J., \& Vacas, J. A. (2014). Design of an accurate, low-cost autonomous data logger for PV system monitoring using Arduino ${ }^{\mathrm{TM}}$ that complies with IEC standards. Solar Energy materials and solar cells, 130, 529-543. doi: 10.1016/j.solmat.2014.08.008

[6]. Pudin, A., \& Mardiyanto, I. R. (2020). Desain dan Implementasi Data Logger untuk Pengukuran Daya Keluaran Panel Surya dan Iradiasi Matahari. ELKOMIKA: Jurnal Teknik Energi Elektrik, Teknik Telekomunikasi, \& Teknik Elektronika, 8(2), 240.

[7]. Suryawinata, H., Purwanti, D., \& Sunardiyo, S. (2017). Sistem monitoring pada panel surya menggunakan data logger berbasis ATMega 328 dan Real Time Clock DS1307. Jurnal Teknik Elektro, 9(1), 30-36.

[8]. El Hammoumi, A., Motahhir, S., Chalh, A., El Ghzizal, A., \& Derouich, A. (2018). Low-cost virtual instrumentation of PV panel characteristics using Excel and Arduino in comparison with traditional instrumentation. Renewables: wind, water, and solar, 5(1), 1-16. doi: 10.1186/s40807-018-0049-0

[9]. Touati, F., Al-Hitmi, M. A., Chowdhury, N. A., Hamad, J. A., \& Gonzales, A. J. S. P. (2016). Investigation of solar PV performance under Doha weather using a customized measurement and monitoring system. Renewable Energy, 89, 564-577. doi: 10.1016/j.renene.2015.12.046 